\title{
Metal spatial distribution assessment in Phragmites sp. treating pyrite mining acid drainage: X-ray Micro-CT, SEM-EDS and ICP-AES study
}

\author{
L.J.T. Alexandre ${ }^{* * *}$, M.F.C. Pereira ${ }^{* * *}$, A.M. Mauricio ${ }^{* * *}$, S. Martins-Dias ${ }^{* * * *}$
}

*IBB, Institute of Biotechnology and Bioengineering, Instituto Superior Técnico, Universidade de Lisboa, Av. Rovisco Pais, 1049-001, Lisbon, PORTUGAL

** CERENA, Instituto Superior Técnico, Universidade de Lisboa, Av. Rovisco Pais, 1049-001, Lisbon, PORTUGAL

**** CERENA/CEPGIST, Instituto Superior Técnico, Universidade de Lisboa, Av. Rovisco Pais, 1049-001, Lisbon, PORTUGAL

email: mfcp@tecnico.ulisboa.pt

Acid mine drainage (AMD) containing sulphate and heavy metals (HM), e.g., Fe, Mn, $\mathrm{Cu}$ and $\mathrm{Zn}$ in large quantities along with a high acidity and very low $\mathrm{pH}$ is a significant environmental problem throughout the world. The phytoremediation by constructed wetlands $(\mathrm{CW})$ is being increasingly used to treat such contaminating discharges [1]. The present study was conducted to investigate HM removal efficiency from AMD of a pilot $\mathrm{CW}$ planted with Phragmites $s p$. in light expanded clay aggregates (Leca®). AMD was collected at Aljustrel pyrite mine (south Portugal - Iberian Pyrite Belt) retention basin. Role of vegetation in the system was assessed by HM concentration and distribution in the Phragmites tissues. Three main techniques were selected to analyse metal distribution: ICP-AES (Inductively Coupled Plasma - Atomic Emission Spectroscopy), $\mu \mathrm{CT}$ (X-Ray Computed Micro-Tomography) and SEM-EDS (Scanning Electron Microscopy - Energy Dispersive Spectroscopy).

A pilot CW $\left(0.64 \mathrm{~m}^{2} \times 0.8 \mathrm{~m}\right)$ was fed in a continuous vertical flow (VF) mode with AMD during a two years period under different operating conditions. Table 1 resumes inlet and outlet HM content of AMD fed to the VFCW in two selected periods. Inlet hydraulic loads of $50 \mathrm{Lm}^{-2} \mathrm{~d}^{-1}$ (Trial 8) and $100 \mathrm{Lm}^{-2} \mathrm{~d}^{-1}$ (Trial 10) were considered. Plant tissues' were sampled immediately after the trials. Plant tissues' from a VFCW fed with tap water was considered as control.HM were quantified by ICP-AES. The high Fe removal efficiencies along with a rocket increase of Fe content observed in the roots (Table 1) was intriguing, as plants did not show any sign of toxicity.

Tomographic perspectives of control and selected contaminated Phragmites roots' and rhizomes are show in Figure 1. Some opaque regions (minute white spots) are seen in the contaminated plants. The SEM-EDS results suggest the existence of local HM concentration, especially Fe, related to the sulphate acidic water. Control samples do not show the presence of the contamination metals ( $\mathrm{Fe}, \mathrm{Mn}, \mathrm{Zn}, \mathrm{Cu}$ ). There are also differences in the metal distribution between different parts of the plant, as concluded by ICP-AES.

Fe plaques in the roots and nodular bodies inside of the xylem are seen in restricted regions (Fig. 2) [2][3]. Leafs are depleted in that metals (Fig. 2). $\mathrm{Cu}$ and $\mathrm{Zn}$ can also be accumulated in the roots but a more random distribution pattern is found. Combining both $\mu \mathrm{CT}$ and SEM-EDS results, it is possible to conclude that the present methodology is adequate to perform studies concerning the phytoremediation studies using hyper accumulative plants, as is the case of the Phragmites sp..

The authors acknowledge FCT for PEst-OE/CTE/UI0098/2011 and Lília J.T. Alexandre SFRH/BD/39800/2008 grant. 
[1] Batty L.C. and Younger P.L., Environmental Pollution, 132, 85-93, 2004.

[2] Kleche M. et al., Annals of Biological Research, 4, 130-133, 2013.

[3] Hansel C.M. et al., Environmental Sciences Technology, 35, 3863-3868, 2001.

Table 1. Performance of the VFCW planted with Phragmites $s p$. in Leca ${ }^{\circledR}$ treating an acid mine drainage under aerobic conditions. $\mathrm{HM}$ distribution in Phragmites leaf and root tissues. $\mathrm{SO}_{4}{ }^{2-}$ correspond to soluble sulphates.

\begin{tabular}{|c|c|c|c|c|c|c|c|c|c|c|}
\hline & \multicolumn{2}{|c|}{ Trial 8} & \multicolumn{2}{|c|}{ Trial 10} & \multicolumn{2}{|c|}{ Control } & \multicolumn{2}{|c|}{ Trial 8} & \multicolumn{2}{|c|}{ Trial 10} \\
\hline & & Out & & Out & $\begin{array}{r}\text { Root } \\
\mathrm{mg} /\end{array}$ & $\begin{array}{l}\text { Leaf } \\
\text { d.w. }\end{array}$ & $\begin{array}{r}\text { Root } \\
\mathrm{mg}\end{array}$ & $\begin{array}{l}\text { Leaf } \\
\text { d.w. }\end{array}$ & $\begin{array}{l}\text { Root } \\
\mathrm{mg} / \mathrm{l}\end{array}$ & $\begin{array}{l}\text { Leaf } \\
\text { d.w. }\end{array}$ \\
\hline & 260 & 84 & 230 & 47 & 2290 & 72 & 3372 & 203 & 9788 & 232 \\
\hline Mn & 4.5 & 4.3 & 4.8 & 4.9 & 59.3 & 67.5 & 106 & 118 & 58.8 & 42.1 \\
\hline $\mathrm{Cu}$ & 15.4 & 13.3 & 15.3 & 13.9 & 47.4 & 13.3 & 62.3 & 4.7 & 72.5 & 4.1 \\
\hline $\mathrm{Zn}$ & 25.7 & 23.8 & 26.2 & 25.3 & 156 & 19.1 & 171 & 112 & 157 & 42.1 \\
\hline $\mathrm{SO}_{4}{ }^{2-}$ & 2107 & 1693 & 2776 & 2180 & 4370 & 7710 & 5300 & 26900 & 6500 & 3400 \\
\hline $\mathrm{pH}$ & 2.6 & 2.8 & 2.5 & 2.8 & & & & & & \\
\hline
\end{tabular}

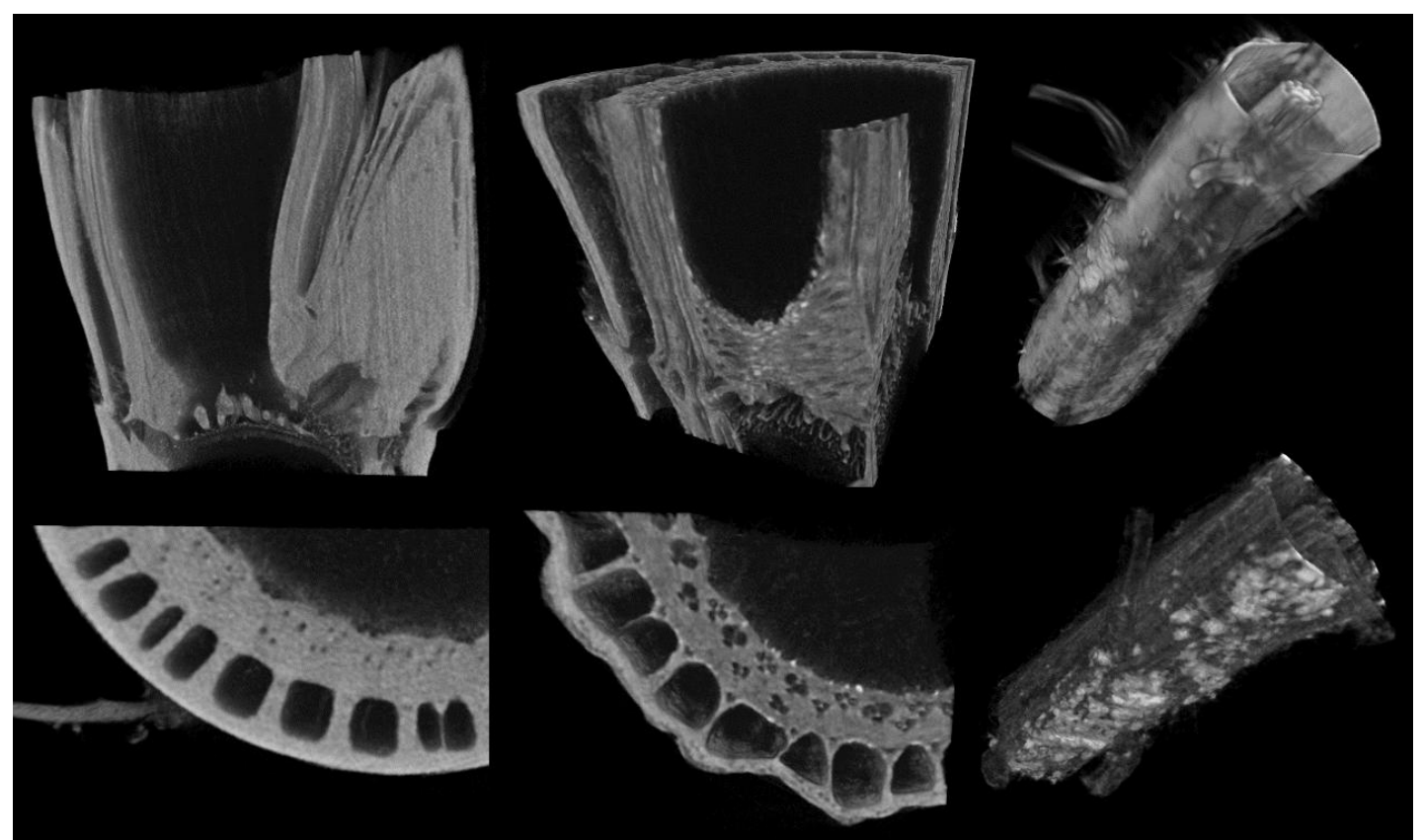

Figure 1 - Tomographic 3D models: control (left images) and trial 8 contaminated rhizomes (central images); control (top right image) and trial 8 contaminated root (bottom right image).

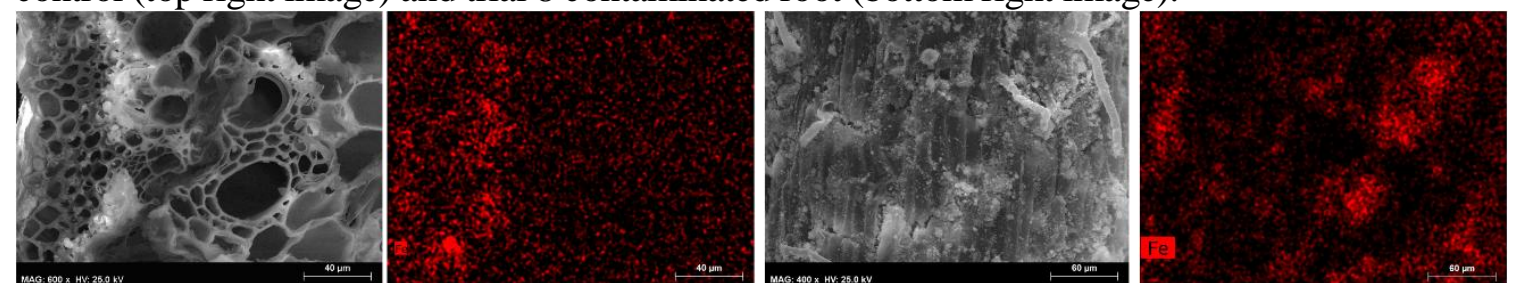

Figure 2 - SEM-EDS images: intra-rhizome Fe concentration (left) and Fe rich external plaques in the roots (right) from trial 10. 